This is the author's final, peer-reviewed manuscript as accepted for publication. The publisher-formatted version may be available through the publisher's web site or your institution's library.

\title{
Characterising the chemistry of micropores in a sodic soil with strong texture-contrast using synchrotron X-ray techniques and LA-ICP-MS
}

Laurence Jassogne, Ganga Hettiarachchi, Ann McNeill, David Chittleborough

\section{How to cite this manuscript}

If you make reference to this version of the manuscript, use the following information:

Jassogne, L., Hettiarachchi, G., McNeill, A., \& Chittleborough, D. (2012). Characterising the chemistry of micropores in a sodic soil with strong texture-contrast using synchrotron X-ray techniques and LA-ICP-MS. Retrieved from http://krex.ksu.edu

\section{Published Version Information}

Citation: Jassogne, L., Hettiarachchi, G., McNeill, A., \& Chittleborough, D. (2012). Characterising the chemistry of micropores in a sodic soil with strong texture-contrast using synchrotron X-ray techniques and LA-ICP-MS. Soil Research, 50(5), 424-435.

Copyright: (C) CSIRO

Digital Object Identifier (DOI): doi:10.1071/SR11312

Publisher's Link: http://www.publish.csiro.au/?paper=SR11312

This item was retrieved from the K-State Research Exchange (K-REx), the institutional repository of Kansas State University. K-REx is available at http://krex.ksu.edu 
2 Characterising the chemistry of micropores in a sodic soil with strong texture-

3 contrast using synchrotron X-ray techniques and LA-ICP-MS

4 Laurence Jassogne $^{1}$, Ganga Hettiarachchi*2,3 ${ }^{2,}$ Ann McNeill ${ }^{3}$, David Chittleborough ${ }^{4}$

$6{ }^{1}$ School of Plant Biology, University of Western Australia, Crawley Western

7 Australia, 6907

$8 \quad{ }^{2}$ Department of Agronomy, Kansas State University, Manhattan, KS 66506, USA

$9{ }^{3}$ School of Agriculture, Food and Wine, University of Adelaide, Waite Campus, PMB

10 1, Glen Osmond, SA, 5064 Australia.

$11{ }^{3}$ School of Earth and Environmental Sciences, University of Adelaide, Waite Campus,

12 PMB 1, Glen Osmond, SA, 5064 Australia

$13 \quad{ }^{*}$ corresponding author; e-mail: ganga@ksu.edu

14 Phone: 785-532-7209

15 Fax: 785-532-6094

16 Acknowledgments:

17 We thank the Australian government for the International Postgraduate Research

18 Scholarship of Laurence Jassogne. We would also like to thank Prof. Hans Lambers

19 for support. This work was performed at GeoSoilEnviroCARS (Sector 13), Advanced

20 Photon Source (APS), Argonne National Laboratory. GeoSoilEnviroCARS is

21 supported by the National Science Foundation - Earth Sciences (EAR-0622171) and

22 Department of Energy - Geosciences (DE-FG02-94ER14466). Use of the Advanced

23 Photon Source was supported by the U. S. Department of Energy, Office of Science,

24 Office of Basic Energy Sciences, under Contract No. DE-AC02-06CH11357. We

25 especially want to thank Matt Newville at GSECARS for the invaluable suggestions 
1 for sample setup and support for XRF/XAS data collection. The authors would also

2 like to thank Angus Netting for the help with LA-ICP-MS analysis at Adelaide

3 Microscopy. This work was supported by an AINSE grant (No. 06/030P) and by the

4 Australian Synchrotron Research Program (ASRP) which is funded by the

5 Commonwealth of Australia under Major National Research Facilities Program. The

6 Cooperative Research Centre for Plant-based Management of Dryland Salinity also

7 partly funded this research.

8

9

10

11

12

13

14

15

16

17

18

19

20

21

22

23

24

25 
2 Soils with strong texture contrast between A and B horizons dominate the agricultural 3 zones of western and southern Australia. The B horizon is often sodic, of much finer

4 texture than the A (or E) horizon above and can have a bulk density as high as $2 \mathrm{g.cm}^{-}$

$5{ }^{3}$. When dry, these B horizons may severely impede the root growth of annual cereal

6 crops. The objective of this study was to characterise the mineralogy and chemistry of

7 fine pores at the interface of an E and sodic B horizon of an Alfisol (Sodosol). Micro-

8 X-ray fluorescence spectroscopy ( $\mu$-XRF) was used to locate the distribution of

9 calcium $(\mathrm{Ca})$, manganese $(\mathrm{Mn})$, iron $(\mathrm{Fe})$, zinc $(\mathrm{Zn})$ and copper $(\mathrm{Cu})$, and $\mu$-X-ray

10 absorption near edge structure ( $\mu$-XANES) spectroscopy to investigate speciation of

$11 \mathrm{Fe}, \mathrm{Mn}, \mathrm{Zn}$ and $\mathrm{Cu}$ around a pore. Both natural aggregates and thin sections were

12 employed but measurements from thin sections were more useful because of the

13 smaller thickness of the sample. The distribution maps showed that $\mathrm{Ca}$ was present in

14 the pores but not the other elements. Copper, $\mathrm{Mn}$ and $\mathrm{Zn}$ were concentrated around

15 the micropore. Manganese was always well correlated with Fe.

16 Manganese was found in reduced form (i.e., Mn (II)) and associated with phosphates

17 whereas Fe was in oxidised form and mostly associated with oxides. Zinc was mostly 18 associated with carbonates $\left(\mathrm{CO}_{3}\right)$, sulfates $\left(\mathrm{SO}_{4}\right)$ and silicates $\left(\mathrm{SiO}_{4}\right)$. The results were

19 then compared with measurements by Laser Ablation Inductively Coupled Plasma

20 Mass Spectrometry (LA-ICP-MS). Only some observations made by $\mu$-XRF were

21 confirmed by LA-ICP-MS, most probably because of the superior detection limits of

22 synchrotron based $\mu-X R F$. 
3 Soils with strong texture contrast between surface and B horizons, called duplex soils

4 in Australia, dominate the agricultural zones of western and southern Australia. The A

5 and E horizons of such soils are usually coarse-textured and of low nutrient content

6 and water holding capacity. The B horizon has a much finer texture than the surface

7 horizons and can have a bulk density as high as $2 \mathrm{~g} \mathrm{~cm}^{-3}$ (Chittleborough 1992). High

8 soil strength causes mechanical resistance to root penetration. Furthermore, root

9 growth can be impeded because of seasonal waterlogging caused by a perched

10 watertable on the dense, high-strength sodic B horizon (Adcock et al. 2007). Roots

11 growing through the B-horizon of texture-contrast soils can use pores that extend

12 many meters through the profile (Yunusa et al. 2002). These biopores, presumably

13 created by native perennial vegetation, not only provide pathways through the soil

14 otherwise impenetrable by many plants, but also improve exposure to preferential

15 flows of oxygen, water and nutrients (Bouma 1992; Eldridge and Freudenberger

16 2005).

17 Roots change the chemical, physical and biological properties of the soil in which

18 they grow and the zone of soil in which these changes occur is called the rhizosphere

19 (Hinsinger et al. 2006). These effects can be direct, such as the exudation of protons

20 which lower soil $\mathrm{pH}$ thereby facilitating access to nutrients, or indirect, such as the

21 exudation of organic molecules that can be used as substrate by soil microbes. In a

22 root system, fine roots $(<0.8 \mathrm{~mm})$ and root hairs are responsible for water and

23 nutrient uptake (McCully 1999). These roots will be located in the meso- and

24 micropores of a structured soil. Micropores, also called matrix pores, occur between 
1 individual mineral grains and soil particles and are not generally created by soil biota

2 (Eldridge and Freudenberger 2005).

3 The rhizosphere develops, matures and senesces in parallel with developmental

4 changes in adjacent regions of the subtending root and remains as a relic after root

5 death, often as a biopore which, in hard soils, is occupied by roots of subsequent crops

6 (McCully 2005). Stewart et al. (1999) defined the macropore sheath as the zone

7 around a macropore in which $80 \%$ of the roots in the soil are located. In "hostile"

8 soils, the macropore sheath is small and the roots are concentrated in the immediate

9 vicinity of the macropore. "Hostile" is a descriptor that has been used to convey the

10 difficulty of many introduced crop and pasture plants to cope with duplex soils having

11 high strength B horizons. In less hostile soils, the influence of the macropore sheath

12 extends further into the soil matrix and roots are more evenly distributed in the soil.

13 Few studies have looked at the chemistry of remnant rhizospheres in soil. Most

14 studies have been carried out at the scale of millimeters and on soils in which the

15 natural structure has been destroyed. In the study by Stewart et al. (1999) a $3 \mathrm{~mm}$

16 annulus around the macropore was scraped and separated from the matrix and

17 analysed for several elements and microbiological activity. Studies on duplex soils

18 have shown that the environment around such a macropore has higher organic $\mathrm{C}$, total

$19 \mathrm{~N}$, bicarbonate-extractable $\mathrm{P}, \mathrm{Ca}, \mathrm{Cu}, \mathrm{Fe}$ and $\mathrm{Mn}$, and supported higher populations of

20 bacteria, fungi and actinomycetes (i.e. Pseudomonas spp., Bacillus spp., cellulolytic

21 bacteria, cellulolytic fungi, nitrifying bacteria and the root pathogen Pythium) than the

22 bulk soil (Pierret et al. 1999; Pankhurst et al. 2002).

23 Because root growth in hostile subsoils is dependent on pore character, there is a

24 need to understand the distribution of nutrients in relation to pore surfaces. The

25 distribution of micronutrients, the highly heterogeneous nature of soils and especially 
1 their pore surfaces, require techniques capable of high resolution and high surface

2 sensitivity. In a previous study Jassogne et al. (2009) employed synchrotron based X-

3 ray techniques to produce high resolution maps of the distribution of $\mathrm{Ca}, \mathrm{Mn}, \mathrm{Fe}, \mathrm{Zn}$

4 and $\mathrm{Cu}$. Synchrotron radiation allowed differentiation of these elements with greater

5 certainty than normal X-ray techniques of lower resolution. Our previous study

6 (Jassogne et al. 2009) showed no detectable difference in speciation of these elements

7 at the pore surface and $<500 \mu \mathrm{m}$ from it. We concluded although the influence of the

8 micropore was to concentrate macro- and/or micronutrients within and/or in the

9 immediate vicinity, there was no significant influence of the micropore on the

10 chemical form of these elements. We also concluded that a larger area around the

11 micropore should be studied to investigate whether the influence on the chemical

12 form of these elements varies with scale.

13

14 There is a paucity of information at the nano- and micro-scale of the effect of roots on 15 the chemistry of the pore surface and to what extent synchrotron based X-ray

16 fluorescence ( $\mu$-XRF) and X-ray absorption near edge spectroscopy (XANES) can aid

17 in these investigations. The X-ray beam can be focused to a spot size of amplitude of

18 a couple of $\mu \mathrm{m}$ to $25-50 \mu \mathrm{m}$, depending on the beamline, using a combined harmonic

19 rejection/vertical mirror. A study by Voegelin et al. (2007) used these techniques to

20 investigate the distribution and speciation of arsenic (As) around roots in thin sections

21 of riparian soils. The analysis of soil thin sections by $\mu$-XRF and XANES has also

22 been employed to investigate the speciation of $\mathrm{Zn}$ in clay soils (Isaure et al. 2005;

23 Manceau et al. 2004) and the geochemistry of As, Se and Fe in soil developed in

24 pyritic shale materials (Strawn et al. 2002). The benefit of using thin sections is that

25 the surface is smooth and flat. Thin sections are also easier to handle than intact 
1 samples. Nevertheless, impregnating a soil sample with a resin is invasive and the

2 chemistry and structure of the sample could be altered. Drying the sample too quickly

3 with acetone can make roots shrink and can give a misrepresentation of the soil/root

4 contact. However, thin sections can be prepared in such a manner that the interface

5 between soil and root is only minimally perturbed (Vannoordwijk et al. 1992).

6 In this study we analyse aggregates of soil in which the original structure has been

7 maintained and thin sections of undisturbed soil at micrometer-scale in order to

8 resolve the distribution of $\mathrm{Ca}, \mathrm{Fe}, \mathrm{Mn}, \mathrm{Zn}$ and $\mathrm{Cu}$ around micropores by $\mu$-XRF and

9 their speciation by XANES. The locus of our study was the E horizon-B horizon

10 boundary, the site in the profile of abrupt texture contrast. Because of the novelty of

11 this study, it was important to investigate other techniques that could confirm our

12 findings. In a previous study by Jassogne et al. (2009) some observations by X-ray

13 absorption spectroscopy were confirmed by scanning electron microscopy fitted with

14 an energy-dispersive X-ray analyser (SEM-EDXA), but the instrument was not

15 sensitive enough to study all the elements of interest. Because LA-ICP-MS can

16 provide spatially-resolved information at ppm detection limits for many elements

17 (Jimenez et al. 2007) this technique was employed. In this paper, LA-ICP-MS was

18 used to determine the distribution of $\mathrm{Ca}, \mathrm{Mn}, \mathrm{Fe}, \mathrm{Zn}$ and $\mathrm{Cu}$ along a transect crossing

19 a micropore.

\section{MATERIALS AND METHODS}

23 Intact soil cores (50 cm long, $15 \mathrm{~cm}$ diameter) were taken from an agricultural site in

24 southern Australia ( $\left.33^{\circ} 54^{\prime} \mathrm{S}, 137^{\circ} 47^{\prime} \mathrm{E}\right)$. The soil was a Red Sodosol in the

25 Australian Soil Classification (Isbell 1996) or a Typic Natrixeralf (Soil Survey Staff 
1 1999). It consisted of $A$ and $E$ horizons of sand texture overlying a sodic B horizon of

2 clay texture at approximately $35 \mathrm{~cm}$. The general characteristics of this soil are

3 presented in another paper (Jassogne et al. 2009). Intact soil segments $(10 \mathrm{~cm} \times 10 \mathrm{~cm}$

$4 \times 10 \mathrm{~cm}$ ) were excised from the zone around the E-B boundary (hereafter called the

5 interface). These segments were impregnated with an epoxy resin and sections of

6 thickness $20 \mu \mathrm{m}$ prepared. Soil clods (approx. $1.5 \mathrm{~cm} \times 1.5 \mathrm{~cm} \times 0.7 \mathrm{~cm}$ ) were

7 isolated from the interface. A criterion for selection of the clods for analysis was that

8 they had distinguishable root channels on their outer surfaces. Micropores were

9 selected on two of the clods. The channels selected for analysis in thin sections were

10 those containing either a decaying root or organic coatings on their surfaces (Figure

11 1). In two small pores at the top of the $B$ horizon it was possible to excise with a fine

12 needle and scalpel a sufficient and coherent amount of organic material for

13 radiocarbon analysis at the Australian Nuclear Science and Technology Facility near

14 Sydney by accelerator mass spectrometry. Ages were 250 and 450 years BP.

15 The distribution of $\mathrm{Fe}, \mathrm{Mn}, \mathrm{Cu}, \mathrm{Zn}$ and $\mathrm{Ca}$ around the selected pores were mapped by

$16 \mu-\mathrm{XRF}$, the speciation of Mn, Fe and Zn by $\mu$-XANES and that of Cu by $\mu$-X-ray

17 absorption fine structure spectroscopy ( $\mu$-XAFS). The $\mu-X R F, \mu-X A N E S$ and

$18 \mu$-XAFS data were collected at beamline 13-BM-GSECARS

19 (GeoSoilEnviroConsortium of Advanced Radiation Sources) at the Advanced Photon

20 Source (APS) at Argonne National Laboratory, Argonne, IL. The electron storage ring

21 operated at $7 \mathrm{GeV}$ with a top-up fill status. This bending magnet beamline is

22 specialised for earth and environmental science research. The $\mu-X R F$ maps and

$23 \mu$-XANES spectra were collected at ambient temperature in fluorescence mode

24 except for the $\mu$-XANES spectra of the standards that were collected in transmission

25 mode. The $\mu-\mathrm{XRF}$ microprobe at APS beamline 13-BM is capable of collecting 
1 fluorescence data with a $10-30 \mu \mathrm{m}$ beam spot size range and 10 to $50 \mathrm{mg} \mathrm{kg}^{-1}$

2 sensitivity, thereby allowing the study of elements at low concentration in complex

3 soil samples.

4 The XRF maps were taken at two energies. The high energy map was taken at 10500

$5 \mathrm{keV}$ and showed the distribution of $\mathrm{Fe}, \mathrm{Zn}$ and $\mathrm{Cu}$. The low energy map was taken at

6 energy of $7050 \mathrm{eV}$. This is below the absorption edge of Fe to avoid interference from

7 background Fe fluorescence for elements (in our study, Mn) with an absorption edge

8 less than that of $\mathrm{Fe}$ and located close to the Fe absorption edge.

9 The intact samples and the thin sections were mounted on the rotation axis of an $x-y-$

$10 \theta$ stepping motor stage. Fluorescence data were collected for a $10,000 \mu \mathrm{m}$ by $200 \mu \mathrm{m}$

11 area on the first intact sample, a $10,000 \mu \mathrm{m}$ by $950 \mu \mathrm{m}$ area on the second intact

12 sample and two $2,400 \mu \mathrm{m}$ by $1000 \mu \mathrm{m}$ areas on the thin section. The step size was 50

$13 \mu \mathrm{m}$ for the intact sample and $25 \mu \mathrm{m}$ for the thin sections using a solid-state energy

14 dispersive X-ray detector that allowed simultaneous detection of fluorescence signals

15 from multiple elements. Aluminium foil was used to diminish the background

16 fluorescence from Fe. The fluorescence signal from a given element is proportional to

17 the integrated number of atoms of that element along thetransect of the synchrotron

18 beam.

19 'Hotspots'(zones of relatively high concentration) of the elements of interest were

20 chosen based on the XRF maps. Selecting these points allowed collection of XAFS

21 spectra, especially for elements present in very low concentrations. Hotspots were

22 randomly selected for each element ( $\mathrm{Mn}, \mathrm{Fe}, \mathrm{Cu}$ and $\mathrm{Zn}$ ), some close to the pore

23 surface, some further into the soil matrix. A similar procedure was adopted for the

24 thin section analysis. Three $\mu$-XANES spectra were collected over the energy range

25 of -200 to $+600 \mathrm{eV}$ above the K-edge. The XANES and EXAFS spectra were 
1 collected around the absorption edges of the elements of interest: Mn; $6539 \mathrm{eV}, \mathrm{Fe}$ :

$27112 \mathrm{eV}, \mathrm{Cu}: 8979 \mathrm{eV}$ and Zn: $9659 \mathrm{eV}$. Additionally, the XANES and EXAFS

3 spectra of $\mathrm{Fe}, \mathrm{Mn}, \mathrm{Cu}$ and $\mathrm{Zn}$ standards were collected. Standards were chosen

4 carefully according to the knowledge of the type of soil. For example, the soil had a

5 strong red colour which indicated that it potentially contained much oxidised Fe. The

6 standards selected for $\mathrm{Fe}$ were fayalite $\left(\mathrm{Fe}_{2} \mathrm{SiO}_{4}\right)$, magnetite $\left(\mathrm{Fe}_{3} \mathrm{O}_{4}\right)$, goethite

$7(\mathrm{FeOOH})$, siderite $\left(\mathrm{FeCO}_{3}\right)$, vivianite $\left(\mathrm{Fe}_{3}\left(\mathrm{PO}_{4}\right) \cdot 8 \mathrm{H}_{2} \mathrm{O}\right)$, hematite $\left(\mathrm{Fe}_{2} \mathrm{O}_{3}\right)$, greenrust-

$8 \quad \mathrm{Cl}\left(\left(\mathrm{Fe}, \mathrm{Mg}^{2+}\right)_{6}\left(\mathrm{Fe}^{3+}\right)_{2}(\mathrm{OH})_{18} \cdot 4\left(\mathrm{H}_{2} \mathrm{O}\right)_{18} \mathrm{Cl}\right)$, greenrust-

$9 \quad\left(\left(\mathrm{Fe}, \mathrm{Mg}^{2+}\right)_{6}\left(\mathrm{Fe}^{3+}\right)_{2}(\mathrm{OH})_{18} \cdot 4\left(\mathrm{H}_{2} \mathrm{O}\right)_{18} \mathrm{SO}_{4}\right) .$. The standards selected for Mn were

10 birnessite $\left((\mathrm{Na}, \mathrm{Ca})_{0.5}\left(\mathrm{Mn}^{4+}, \mathrm{Mn}^{3+}\right)_{2} \mathrm{O}_{4} \cdot 1.5 \mathrm{H}_{2} \mathrm{O}\right)$, hureaulite ((Mn, $\left.\left.\mathrm{Fe}\right)_{5} \mathrm{H}_{2}\left(\mathrm{PO}_{4}\right)_{4} \cdot 4 \mathrm{H}_{2} \mathrm{O}\right)$,

11 manganocalcite $\left(\mathrm{Mn}-\mathrm{CaCO}_{3}\right), \mathrm{Mn}$-carbonate $\left(\mathrm{MnCO}_{3}\right), \mathrm{Mn}$-sulfate $\left(\mathrm{MnSO}_{4}\right)$, bixbyite

$12\left(\mathrm{Mn}_{2} \mathrm{O}_{3}\right)$, pyrolusite $\left(\mathrm{MnO}_{2}\right)$ and switzrite $\left((\mathrm{Mn}, \mathrm{Fe})_{3}\left(\mathrm{PO}_{4}\right)_{2} \cdot 7 \mathrm{H}_{2} \mathrm{O}\right)$. The standards

13 selected for $\mathrm{Cu}$ were azurite $\left(\mathrm{Cu}_{3}\left(\mathrm{CO}_{3}\right)_{2}(\mathrm{OH})_{2}\right)$, calcosiderite

$14\left(\mathrm{Cu}, \mathrm{Fe}_{6}\left(\mathrm{PO}_{4}\right)_{4}(\mathrm{OH})_{8} \cdot 4\left(\mathrm{H}_{2} \mathrm{O}\right)\right)$, cuprite $\left(\mathrm{Cu}_{2} \mathrm{O}\right)$, libethenite $\left(\mathrm{Cu}_{2}\left(\mathrm{PO}_{4}\right)(\mathrm{OH})\right)$, malachite

$15\left(\mathrm{Cu}_{2}\left(\mathrm{CO}_{3}\right)(\mathrm{OH})_{2}\right)$, nissonite $\left(\mathrm{Cu}_{2} \mathrm{Mg}_{2}\left(\mathrm{PO}_{4}\right)_{2}(\mathrm{OH})_{2} \cdot 5\left(\mathrm{H}_{2} \mathrm{O}\right)\right)$, pseudomalachite

$16\left(\mathrm{Cu}_{5}\left(\mathrm{PO}_{4}\right)_{2}(\mathrm{OH})_{4}\right)$, tenorite $(\mathrm{CuO})$ and $\mathrm{CuSO}_{4}$. The standards selected for $\mathrm{Zn}$ were

17 ferrihydrite adsorbed $\mathrm{Zn}\left(\mathrm{Zn}-\mathrm{Fe}_{5} \mathrm{O}_{3}(\mathrm{OH})_{9}\right)$, franklenite

$\left.18\left(\mathrm{Zn}, \mathrm{Mn}^{2+}, \mathrm{Fe}^{2+}\right)\left(\mathrm{Fe}^{3+}, \mathrm{Mn}^{3+}\right)_{2} \mathrm{O}_{4}\right)$, hopeite $\left(\mathrm{Zn}_{3}\left(\mathrm{PO}_{4}\right)_{2} \cdot 4\left(\mathrm{H}_{2} \mathrm{O}\right)\right)$, hydrozincite

$19\left(\left(\mathrm{Zn}_{5}\left(\mathrm{CO}_{3}\right)_{2}(\mathrm{OH})_{6}\right)\right.$, scholzite $\left(\mathrm{CaZn}_{2}\left(\mathrm{PO}_{4}\right)_{2} \cdot 2\left(\mathrm{H}_{2} \mathrm{O}\right)\right)$, smithsonite $\left(\mathrm{ZnCO}_{3}\right)$, willemite

$20 \quad\left(\mathrm{Zn}_{2} \mathrm{SiO}_{4}\right)$ and zn-sulfate $\left(\mathrm{ZnSO}_{4}\right)$.

21 The XANES spectra of the randomly chosen hotspots were averaged, the edge energy

22 calibrated and the spectrum normalised. Linear combination fitting (LCF) was applied

23 using IFEFFIT software on the pre-processed XANES spectra of the hotspots

24 (Newville 2001). For each selected hotspot, the combination with the lowest $\chi^{2}$ was

25 chosen as the most likely combination of compounds in that hotspot. The accuracy of 
1 the fitting depends on how well the standards represent the data. A reduced $\chi^{2}$ smaller

2 than 1 indicated a reliable fit. Owing to the limited number of standards, the best fit

3 composition may not give the true composition, although it can provide an indication

4 of primary forms of the element of interest and describe the chemical differences

5 among the selected hotspots in a spatially-resolved manner.

6 Subsequently, impregnated soil samples were chemically analysed with an Agilent

$7 \quad 7500 \mathrm{cs}$ ICP MS. The regions of interest were ablated using a high performance New

8 Wave Nd Yag 213 UV laser. An optical microscope was used to find pores in the

9 impregnated samples with a thickness of approximately $0.5 \mathrm{~cm}$ and a length of $3 \mathrm{~cm}$.

10 The pores did not always obviously contain organic matter. With the laser, the

11 samples were ablated across the micropores over a length of $2 \mathrm{~mm}$. The laser ablated

12 at a speed of $10 \mu \mathrm{m} \mathrm{s}^{-1}$ and the spotsize was $30 \mu \mathrm{m}$. The sensitivity was $4.7 \mathrm{mg} \mathrm{l}^{-1}$ for

$13 \mathrm{Ca} ; 280 \mathrm{ng} \mathrm{l}^{-1}$ for $\mathrm{Mn} ; 86 \mu \mathrm{g}^{-1}$ for Fe; $1.9 \mu \mathrm{g} \mathrm{l}^{-1}$ for $\mathrm{Zn}$ and $290 \mathrm{ng} \mathrm{l}^{-1}$ for $\mathrm{Cu}$.

14 Measurements were qualitative and only gave a representation of the depletion or

15 accumulation of elements along the micropore. For quantitative measurements,

16 calibration is necessary. This could be done with homogeneous samples. However,

17 this would have defeated the purpose of the study insofar as our objective was to

18 characterise the heterogeneity of the elements in the immediate vicinity of micropores

19 in which we were interested. Another reason why quantitative measures were not

20 possible was that the depth to which the laser ablated, and hence the volume of soil

21 nebulised, was not always constant (Weis et al. 2005). 
1 Of the few pores from the intact samples and the thin sections that were studied only

2 one representative of each sample type was selected for consideration in this section

3 of the paper. An intact sample containing a black decaying root was scanned over an

4 area of $1 \mathrm{~cm}$ by $0.2 \mathrm{~cm}$. The XRF images showed that Ca was concentrated in the

5 channel containing the root (Figure 1). The pore selected contained organic matter

6 from a decaying root and this may have been a source of the $\mathrm{Ca}$, given that roots can

7 accumulate $\mathrm{Ca}$ (Singh and Jacobson 1979). Another source may be Ca from the soil

8 solution adsorbed onto the organic matter. Pores in the thin sections did not always

9 contain decaying organic matter but pores selected always had coatings of organic

10 matter (Figure 2). As shown on the distribution maps, Ca was also concentrated in the

11 pores (Figure 3). In this case, Ca could have been adsorbed from the soil solution onto

12 the pore surface. So it seems that either root activity concentrates $\mathrm{Ca}$ at pore walls

13 and in pores solely by organic matter decay, or water extraction by roots can be also

14 responsible for accumulation of $\mathrm{Ca}$ in and around pore walls. With the techniques

15 used in the current study (synchrotron based hard x-ray absorptionspectroscopy) it

16 was not possible to directly obtain chemical form(s) of $\mathrm{Ca}$ accumulated in and at the

17 surface of pore walls. These soils were alkaline and $\mathrm{pH}$ generally increases with

18 depth. Co-located elements (i.e., $\mathrm{Cu}$ ) were mainly in carbonate forms and therefore, it

19 is possible $\mathrm{Ca}$ accumulated, at least in part, as $\mathrm{Ca}$ carbonate. There is ample of

20 evidence of $\mathrm{Ca}$ carbonate precipitation occurring in root biopores, and in the

21 rhizosphere (Jaillard 1982; Callot et al. 1983; Hinsinger et al. 1998).

22 The correlation graphs originating from the XRF distribution maps showed that Mn

23 and $\mathrm{Zn}$ were always strongly correlated with $\mathrm{Fe}$ in the intact samples and the thin

24 sections $\left(\mathrm{R}^{2}\right.$ for $\mathrm{Fe}$ and $\mathrm{Mn}=0.93$, Figure 1 and $\mathrm{R}^{2}$ for $\mathrm{Fe}$ and $\mathrm{Mn}=0.92$, Figure 3 ).

25 The correlations of Mn and Fe were based on the low energy maps taken below the 
1 absorption edge of $\mathrm{Fe}$. Calcium and $\mathrm{Cu}$ were much less positively correlated to $\mathrm{Fe}$

2 than $\mathrm{Mn}$ and $\mathrm{Zn}$. Calcium was mainly accumulated in pores whereas $\mathrm{Fe}, \mathrm{Mn}, \mathrm{Cu}$ and

3 Zn were mainly accumulated in soil. Calcium, $\mathrm{Mn}, \mathrm{Zn}$ and $\mathrm{Cu}$ were always more

4 correlated with Fe in the intact samples than in the thin sections, a result that has its

5 explanation in the difference in effective sampling depth of the two sample types.

6 The pores selected were always those exposed on the surface of the samples.

7 Fluorescence x-ray signals measured in these experiments could have escaped from a

8 maximum sample depth of about $50 \mu \mathrm{m}$. Given that intact samples were

9 approximately $10 \mathrm{~mm}$ thick spectral information will have been gathered, not only

10 from the pore surface but also the soil matrix. Because the soil contains a total $\mathrm{Fe}$

11 concentration of approximately $4 \%$, a considerable contribution to the Fe spectral

12 signatures will have come from the matrix. The thickness of the thin sections was only

$1320 \mu \mathrm{m}$; therefore, the influence of matrix Fe would have been less significant.

14 Data from hotspots suggested that most of the Mn existed in reduced form (Table 1).

15 More than $50 \%$ of Mn occurred as Mn phosphate-like species (hureaulite and

16 switzerite) and those species could also contained reduced Fe. In contrast, the Mn

17 hotspots selected in the intact samples had a significant fraction of Mn as Mn (IV)

18 oxides (birnessite and $\mathrm{MnO}_{2}$ ) in addition to $\mathrm{Mn}$ phosphate-like species. This was not

19 observed in the thin sections. It is, however, not certain whether this was an artefact

20 of thin section preparation, beam-induced reduction of $\mathrm{Mn}$ in soil thin sections (i.e.,

21 due to interaction with resin) or due to the fact that larger soil volume was exposed in

22 the intact sample XANES data collection. Furthermore, the measurements close to

23 the pore surface did not differ from the ones further into the soil matrix (Figure 4).

24 In most Sodosols only a small proportion of $\mathrm{Fe}$ is available for plants because of the

25 oxidized form in which the Fe is present. The three chemical conditions and processes 
1 primarily affecting $\mathrm{Fe}$ availability to plants are $\mathrm{pH}$, redox status and chelation

2 (McFarlane 1999). The distribution maps showed that there was no enrichment of Fe

3 around the selected pores (Figure 1 and 3) but that it was distributed randomly

4 throughout the areas chosen for analysis. The XANES spectra suggested that Fe was

5 mostly present in oxidised form (Table 2). Oxide-like bindings such as those of

6 goethite and hematite were found in the hotspots selected in the intact samples and the

7 thin sections. Some spots in the intact samples appeared to contain greenrust-Cl-like

8 and greenrust-sulfate-like bindings but these forms were not found in the thin

9 sections. In contrast, magnetite was always found in the thin sections (except for one

10 hotspot) but never in the intact samples. Greenrust ((Fe,

$\left.\left.11 \mathrm{Mg}^{2+}\right)_{6}\left(\mathrm{Fe}^{3+}\right)_{2}(\mathrm{OH})_{18} \cdot 4\left(\mathrm{H}_{2} \mathrm{O}\right)_{18}\right)$ and magnetite $\left(\mathrm{Fe}_{3} \mathrm{O}_{4}\right)$ both are oxides with a mixture

12 of oxidised and reduced Fe. The only conclusion that could be made was that in the

13 selected hotspots, a mixture of oxidised and reduced Fe was present. The hotspots

14 selected in the thin sections always had a higher proportion of mixed oxidation forms

15 of Fe compared with hotspots selected on the intact samples. Therefore, it could not

16 be concluded that the Fe speciation in the intact sample was different from the ones in

17 the thin sections. The amount of standard used in this type of study is limited. Given

18 that soil is highly heterogeneous we could not state that the bindings in the hotspots

19 were exactly the same as the bindings of the standards. We concluded that, in all these

20 hotspots, Fe-O-like minerals were present and that these were a mixture of $\mathrm{Fe}$ in II

21 and III oxidation state similar to the ones found in the standards (Figure 5). In only

22 one hotspot in the thin section was Fe found in a phosphate binding (vivianite).

23 Zinc sometimes accumulated around the micropores but was also present in higher

24 concentrations away from the pore (Figures 1 and 3). Linear combination fitting of the

25 XANES and EXAFS region of the absorption spectra showed that the speciation of $\mathrm{Zn}$ 
1 for the hotspot at the edge of the pore and further in the soil matrix chosen in the

2 intact samples were very similar and in forms resembling hydrozincite, $\mathrm{Zn}$-sulfate and

3 willemite. The same was found for the hotspots selected on the thin sections: zinc

4 was always found associated with sulfates at the pore surface. Franklenite-like forms

5 were found at the pore edge whereas $\mathrm{Zn}$ adsorbed on ferrihydrite was found in the soil

6 matrix. Only one instance of smithsonite-like bindings was found and this at the pore

7 surface. This could be due to the higher $\mathrm{CO}_{2}$ levels inside soil pores that favour the

8 formation of carbonates. The one occurrence of scholzite was in the soil matrix.

9 Copper was only present in small amounts in the soil $(<10 \mathrm{ppm}$ in the whole soil

10 profile). The XRF maps of the thin sections showed that $\mathrm{Cu}$ was enriched at the edges

11 of the areas where Ca was located or in the same areas (Figure 3). These areas of

12 enrichment were coincident with organic matter coatings. Previous studies have found

13 that $\mathrm{Cu}$ is associated with organic matter (Jacobson et al. 2007). In this study, only

14 two hotspots in the area close to the pore in the thin sections could be analysed

15 because of the low concentration of $\mathrm{Cu}$ in the soil. The components resulting from the

16 linear combination fitting were different for both hotspots. However, both were

17 composed of approximately $70 \%$ carbonate and $30 \%$ phosphate (Table 4 ). Again,

18 this could be due to higher levels of $\mathrm{CO}_{2}$ in and in the vicinity of soil pores, favouring

19 the formation of carbonates.

20 The distribution of elements of interest across a section of a micropore in impregnated

21 samples were measured by LA-ICP-MS and compared with XANES and EXAFS data

22 of the same section. Measurements from $0 \mathrm{~s}$ to $10 \mathrm{~s}$ at the beginning of the $\mathrm{X}$-axis

23 could not be accounted for as the instrument always needed a period to adjust (Figures

247 and 8). By viewing the ablating point on the sample on the screen of the

25 microscope and comparing it with the counts of the elements detected, it was 
1 established that the decrease in counts of silicon $(\mathrm{Si})$ was a sensitive measure of the

2 location of the micropore. Because we can expect Si distribution abundantly all

3 throughout soil but low or closer-to-background concentrations wherever we have

4 pores. The point with the lowest counts was the middle of the pore and this can be

5 attributed to pore geometry viz. approximate cylindrical shape of pores. Although in

6 all of the $\mu$-XRF maps indicated $\mathrm{Ca}$ was concentrated in the micropores $\mathrm{Ca}$ was

7 detected only in some pores by the LA-ICP-MS. The graphs however, show that

8 wherever there was an accumulation of $\mathrm{Ca}$, there was also an accumulation of $\mathrm{Fe}$ and

9 Mn (Figure $7 \mathrm{see} \sim 20 \mathrm{~s}$, Figure 8 see $\sim 10$ to $50 \mathrm{~s}$ ). This is in contradiction with the

10 distribution maps by $\mu$-XRF. The differences are probably a result of the different

11 volumes of soil material sampled during measurement; sampling depth (effective

12 fluorescence signal depth) for $\mu$-XRF was $50 \mu \mathrm{m}$ whereas that for LA-ICP-MS was

13 greater. Because Fe is relatively depleted at the very surface of the micropore, LA-

14 ICP-MS will detect a greater proportion of Fe than $\mu$-XRF. There were accumulations

15 of $\mathrm{Mn}, \mathrm{Zn}$ and $\mathrm{Cu}$ in proximity of the micropore. It should be noted here that care has

16 to be taken when interpreting results obtained by LA-ICP-MS. Elemental

17 fractionation depends on characteristics of the sample such as optical absorption

18 behaviour. In a heterogeneous medium such as soil, this will vary between samples

19 and therefore, overcoming this problem for matrixindependent quantification becomes

20 a problem (Weis et al. 2005). The high degree of heterogeneity of the elements in the

21 samples and their inhomogeneous distribution makes it impossible to have precise and

22 accurate results that allow quantification (Jimenez et al. 2007).

23 Every pore created by roots and used by subsequent roots has a different history. The

24 inhomogeneity in elemental concentration and spatial distribution will be greater at

25 smaller scale than at larger scale. Rhizosphere chemistry will depend on the type of 
1 root (e.g. root hair, mature root), state of decomposition, extent and diversity of

2 occupancy of pore, and types of plants. Further complexity arises from transport of

3 particles in suspension and solutions, a process dependent on a range of factors such

4 as pore size and pore continuity. Surface analytical techniques such as those employed

5 here have a significant role to play in refining our understanding of nutrient form,

6 concentration and availability and how plant roots affect these in space and time.

7 In this investigation we attempted to study microstructure, in as undisturbed condition

8 as possible, by using intact soil aggregates and thin sections prepared following

9 vacuum impregnation with resin. However, many surface-sensitive techniques

10 require a flat surface. Intact samples cannot be polished, and when surfaces are

11 flattened, smearing occurs which alters the organisation of soil particles that could

12 lead to problems when the chemistry of the surface is studied. Soils of low coherence

13 fragment readily. We attempted to study the chemical nature of the rhizosphere across

14 the E horizon-B horizon boundary but the samples fragmented and our study was 15 confined to the upper B horizon.

16

\section{CONCLUSION}

This study shows that one pore can be drastically different from another.

However, there was no difference in chemistry of these elements at the pore surface and $<500 \mu \mathrm{m}$ (Jassogne et al. 2009) to 10,000 $\mu \mathrm{m}$ from it (current study). As observed for micropores in our 2009 study, it appeared that the influence of the micropore was to concentrate $\mathrm{Zn}, \mathrm{Mn}, \mathrm{Cu}$ within and in the immediate vicinity of it but that there was no significant influence of the micropore on the chemical form of these elements. The chemical form of these 3 elements was similar at the pore surface and in the matrix. A 
1 larger area around the micropore may need to be studied to see whether the influence

2 on the chemical form of these elements varies at a larger scale $(>1 \mathrm{~cm})$.

3 The difference in micro-spatial chemistry between the thin sections and the intact

4 samples can be attributed to the thickness of the sample analysed. This resulted in Mn,

$5 \mathrm{Zn}$ and $\mathrm{Cu}$ having stronger correlations with $\mathrm{Fe}$ in the thin sections compared with the

6 intact samples suggesting that thinness of samples is important to define "real"

7 elemental relationships. Differences observed between $\mu$-XRF and LC-ICP-MS can

8 be mainly attributed to lower detection limit of LA-ICP-MS compared to synchrotron

9 based $\mu$-XRF and the differences in effective sampling depths by these techniques.

10 The combination of these non-invasive techniques, especially synchrotron based x-ray

11 techniques, has given more insights in root/soil interactions.

12

\section{REFERENCES}

Adcock D, McNeill AM, McDonald GK, Armstrong RD (2007) Subsoil constraints to crop production on neutral and alkaline soils in south-eastern Australia: a review of current knowledge and management strategies. Australian Journal of Experimental Agriculture 47, 1245-1261.

Bouma J (1992) Influences of soil macroporosity on environmental quality. In 'Advances in Agronomy'. (Ed. DL Sparks) (Academic Press: New York)

Callot G, Chamayou H, Maertens C, Salsac L (1983) Mieux comprendre les interactions sol-racine. Incidence sur la nutrition minérale. INRA, Paris, p 326

Chittleborough DJ (1992) Formation and pedology of duplex soils. Australian Journal of Experimental Agriculture 32, 15-25. 
1 Eldridge DJ, Freudenberger D (2005) Ecosystem wicks: Woodland trees enhance

2 water infiltration in a fragmented agricultural landscape in eastern Australia. Australian Journal of Ecology 30, 336-347.

Hinsinger P (1998) How do plant roots acquire mineral nutrients? Chemical processes involved in the rhizosphere. Adv Agron 64:225-265

Hinsinger P, Plassard C, Jaillard B (2006) Rhizosphere: A new frontier for soil biogeochemistry. Journal of Geochemical Exploration 88, 210-213.

Isaure MP, Manceau A, Geoffroy N, Laboudigue A, Tamura N, Marcus MA (2005) Zinc mobility and speciation in soil covered by contaminated dredged sediment using micrometer-scale and bulk-averaging X-ray fluorescence, absorption and diffraction techniques. Geochimica et Cosmochimica Acta 69, 1173-1198.

Isbell RF (1996) 'The Australian Soil Classification'. (CSIRO publishing: Melbourne)

Jacobson AR, Dousset S, Andreux F, Baveye PC (2007) Electron microprobe and synchrotron X-ray fluorescence mapping of the heterogeneous distribution of copper in high-copper vineyard soils. Environmental Science and Technology 41, 6343-6349.

Jaillard B (1982) Relation entre dynamique de l'eau et organisation morphologique d'un sol calcaire. Science du Sol 20:31-52.

Jaillard B (1987b) Techniques for studying the ionic environment at the soil-root interface. In: Methodology in soil-K research (I.P.I. Ed.). International Potassium Institute, Bâle, pp 231-245.

Jassogne L, Hettiarachchi G, Chittleborough D, McNeill A (2009) Distribution and speciation nutrient elements around micropores. Soil Science Society of America Journal 73, 1319-1326. 
1 Jimenez, MS, Gomez MT, Castillo JR (2007) Multi-element analysis of compost by

2

3

4 laser ablation-inductively coupled plasma mass spectrometry. Talanta $\mathbf{7 2 ,}$ 1141-1148.

Manceau A, Marcus MA, Tamura N, Proux O, Geoffroy N, Lanson B (2004) Natural speciation of $\mathrm{Zn}$ at the micrometer scale in a clayey soil using X-ray fluorescence, absorption, and diffraction. Geochimica et Cosmochimica Acta 68, 2467-2483.

McCully M (2005) The rhizosphere: the key functional unit in plant/soil/microbial interactions in the field. implications for the understanding of allelopathic effects. In 'Proceedings of the 4th World Congress on Allelopathy, "Establishing the Scientific Base"'. (Eds J Harper, M An, H Wu, J Kent) (Centre for Rural Social Research, Charles Sturt University, Waga Waga)

McCully ME (1999) Roots in soil: unearthing the complexities of roots and their rhizospheres. Annual Review of Plant Physiology and Plant Molecular Biology 50, 695-718.

McFarlane JD (1999) Iron. In 'Soil analysis: an interpretation manual' . (Eds KI Peverill, LA Sparrow and DJ Reuter) (CSIRO publishing: Collingwood, Australia)

Newville M (2001) IFEFFIT: interactive XAFS analysis and FEFF fitting. Journal of Synchrotron Radiation 8, 322-324.

Pankhurst CE, Pierret A, Hawke B, Kirby JM (2002) Microbiological and chemical properties of soil associated with macropores at different depths in a redduplex soil in NSW Australia. Plant and Soil 238,11-20. 
1 Pierret A, Moran CJ, Pankhurst CE (1999) Differentiation of soil properties related to the spatial association of wheat roots and soil macropores. Plant and Soil 211, 51-58.

Singh C, Jacobson L (1979) The accumulation and transport of calcium in Barley roots. Physiologia Plantarum 45, 443-447.

Soil Survey Staff (1999) Soil Taxonomy. In 'Agriculture Handbook 436'. (Ed. Natural Resources Conservation Service) (USDA: Washington, DC)

Stewart JB, Moran CJ, Wood JT (1999) Macropore sheath: quantification of plant root and soil macropore association. Plant and Soil 211, 59-67.

Strawn D, Doner H, Zavarin M, McHugo S (2002). Microscale investigation into the geochemistry of arsenic, selenium, and iron in soil developed in pyritic shale materials. Geoderma 108, 237-257.

Vannoordwijk M, Kooistra MJ, Boone FR, Veen BW, Schoonderbeek D (1992) RootSoil Contact of Maize, as Measured by a Thin-Section Technique .1. Validity of the Method. Plant and Soil 139, 109-118.

Voegelin A, Weber FA, Kretzschmar R (2007) Distribution and speciation of arsenic around roots in a contaminated riparian floodplain soil: Micro-XRF element mapping and EXAFS spectroscopy. Geochimica et Cosmochimica Acta 71, 5804-5820.

Weis P, Beck HP, Gunther D (2005) Characterizing ablation and aerosol generation during elemental fractionation on absorption modified lithium tetraborate glasses using LA-ICP-MS. Analytical and Bioanalytical Chemistry 381:212224. 
1 Yunusa IAM, Mele PM, Rab MA, Schefe CR, Beverly CR (2002) Priming of soil structural and hydrological properties by native woody species, annual crops, and a permanent pasture. Australian Journal of Soil Research 40, 207-219.

Figure captions

Figure 1: Distribution maps of $\mathrm{Ca}, \mathrm{Mn}, \mathrm{Fe}, \mathrm{Zn}$ and $\mathrm{Cu}$ around a pore obtained by $\mu$ XRF in an intact sample and the correlation between these elements.

Figure 2: Optical photomicrograph of the pore scanned by $\mu$-XRF on the thin section represented in Figure 3.

Figure 3: Distribution maps of $\mathrm{Ca}, \mathrm{Mn}, \mathrm{Fe}, \mathrm{Zn}$ and $\mathrm{Cu}$ around a pore by $\mu$-XRF in a thin section and the correlation of these elements.

Figure 4: Some spectra and respective linear combination fittings of hotspots of $\mathrm{Mn}$ selected in the immediate vicinity of the pore (close) and in the soil matrix $>5 \mathrm{~mm}$ from the pore surface in the intact samples and $>1 \mathrm{~mm}$ from the pore surface in the thin sections (far).

Figure 5: Some spectra and respective linear combination fittings of hotspots of Fe selected in the immediate vicinity of the pore (close) and in the soil matrix $>5 \mathrm{~mm}$ 
1 from the pore surface in the intact samples and $>1 \mathrm{~mm}$ from the pore surface in the

2 thin sections (far).

3

$4 \quad$ Figure 6: Some spectra and respective linear combination fittings of hotspots of $\mathrm{Zn}$

5 selected in the immediate vicinity of the pore (close) and in the soil matrix $>5 \mathrm{~mm}$

6 from the pore surface in the intact samples and $>1 \mathrm{~mm}$ from the pore surface in the

7 thin sections (far).

8

$9 \quad$ Figure 7: Relative distribution of $\mathrm{Si}, \mathrm{Ca}, \mathrm{Mn}, \mathrm{Fe}, \mathrm{Cu}$ and $\mathrm{Zn}$ across micropore-1 using

10 LA-ICP-MS. Ca is enriched in the pore.

11

12 Figure 8: Relative distribution of $\mathrm{Si}, \mathrm{Ca}, \mathrm{Mn}, \mathrm{Fe}, \mathrm{Cu}$ and $\mathrm{Zn}$ along a line across

13 micropore-2 using LA-ICP-MS. Ca is impoverished in the pore.

14

15

16

17

18

19

20

21

22

23

24

25 


\section{Tables}

2

3 Table 1: Fractions of Mn species in selected 'Mn-hotspots' in the area close and far

4 from the soil micropore in an intact soil sample and in a thin section.

\begin{tabular}{|c|c|c|c|c|c|c|c|}
\hline & & birnessite & hureaulite & switzrite & $\mathrm{Mn}_{2} \mathrm{O}_{3}$ & $\mathrm{MnO}_{2}$ & red- $\chi^{2+}$ \\
\hline \multirow[t]{2}{*}{ close } & & & & & & & \\
\hline & 1 & 0.00 & 0.00 & 0.76 & 0.24 & 0.00 & 0.011 \\
\hline \multirow[t]{3}{*}{ far } & & & & & & & \\
\hline & 2 & 0.11 & 0.66 & 0.25 & 0.00 & 0.00 & 0.018 \\
\hline & 3 & 0.056 & 0.00 & 0.58 & 0.00 & 0.36 & $<0.010$ \\
\hline \multirow[t]{2}{*}{ close_ts ${ }^{+\dagger}$} & & & & & & & \\
\hline & 4 & 0.00 & 0.36 & 0.64 & 0.00 & 0.00 & $<0.010$ \\
\hline
\end{tabular}

9

$10+{ }^{+} \chi^{2}=\Sigma[(\text { fit }- \text { data }) / \varepsilon]^{2} /\left(\mathrm{N}_{\text {data }}-\mathrm{N}_{\text {components }}\right)$ is the chi-square statistic. Here $\varepsilon$ is the

11 estimated uncertainty in the normalized XANES data (taken as 0.01 for all data). The

12 sum is over $\mathrm{N}_{\text {data }}$ points and $\mathrm{N}_{\text {components }}$ is the number of components in the fit. The

13 total percentage was constrained to be $100 \%$ in all fits. Typical uncertainties in the

14 fractions listed for each standard component are 5\%.

$15{ }^{+t}$ ts: thin section

16

17

18

19

20

21

22

23

24 
1 Table 2: Fractions of Fe species in selected 'Fe-hotspots' in the area close and far

2 from the soil micropore in an intact soil sample and in a thin section

\begin{tabular}{|c|c|c|c|c|c|c|c|c|c|}
\hline 3 & & & $\mathrm{Fe}_{2} \mathrm{O}_{3}$ & goethite & greenrust-Cl & greenrust-S & $\mathrm{Fe}_{3} \mathrm{O}_{4}$ & vivianite & red $-\chi^{2+}$ \\
\hline \multirow{3}{*}{4} & close & & & & & & & & \\
\hline & & 1 & 0.64 & 0.12 & 0.069 & 0.17 & 0.00 & 0.00 & $<0.010$ \\
\hline & & 2 & 0.49 & 0.51 & 0.00 & 0.00 & 0.00 & 0.00 & $<0.010$ \\
\hline \multirow{3}{*}{5} & & 3 & 0.69 & 0.31 & 0.00 & 0.00 & 0.00 & 0.00 & $<0.010$ \\
\hline & far & & & & & & & & \\
\hline & & 4 & 0.58 & 0.42 & 0.00 & 0.00 & 0.00 & 0.00 & $<0.010$ \\
\hline \multirow[t]{2}{*}{6} & & 5 & 0.72 & 0.23 & 0.054 & 0.00 & 0.00 & 0.00 & $<0.010$ \\
\hline & & 6 & 0.05 & 0.95 & 0.00 & 0.00 & 0.00 & 0.00 & $<0.010$ \\
\hline \multirow{3}{*}{7} & close_ts $^{t+}$ & & & & & & & & \\
\hline & & 7 & 0.69 & 0.00 & 0.00 & 0.00 & 0.13 & 0.18 & $<0.010$ \\
\hline & & 8 & 0.59 & 0.41 & 0.00 & 0.00 & 0.00 & 0.00 & $<0.010$ \\
\hline \multirow{3}{*}{8} & & 9 & 0.24 & 0.52 & 0.00 & 0.00 & 0.23 & 0.00 & $<0.010$ \\
\hline & & 10 & 0.26 & 0.56 & 0.00 & 0.00 & 0.18 & 0.00 & $<0.010$ \\
\hline & & 11 & 0.00 & 0.77 & 0.00 & 0.00 & 0.23 & 0.00 & $<0.010$ \\
\hline \multirow[t]{2}{*}{9} & far_ts & & & & & & & & \\
\hline & & 12 & 0.18 & 0.61 & 0.00 & 0.00 & 0.21 & 0.00 & $<0.010$ \\
\hline & & 13 & 0.34 & 0.55 & 0.00 & 0.00 & 0.11 & 0.00 & $<0.010$ \\
\hline
\end{tabular}

11

$12+\chi^{2}=\Sigma[(\text { fit }- \text { data }) / \varepsilon]^{2} /\left(\mathrm{N}_{\text {data }}-\mathrm{N}_{\text {components }}\right)$ is the chi-square statistic. Here $\varepsilon$ is the

13 estimated uncertainty in the normalized XANES data (taken as 0.01 for all data). The

14 sum is over $\mathrm{N}_{\text {data }}$ points and $\mathrm{N}_{\text {components }}$ is the number of components in the fit. The

15 total percentage was constrained to be $100 \%$ in all fits. Typical uncertainties in the

16 fractions listed for each standard component are 5\%.

17

$18{ }^{+\dagger}$ ts: thin section

19

20

21

22

23

24

25 
1 Table 3: Fractions of $\mathrm{Zn}$ species in selected 'Zn-hotspots' in the area close and far

2 from the soil micropore in an intact soil sample and in a thin section.

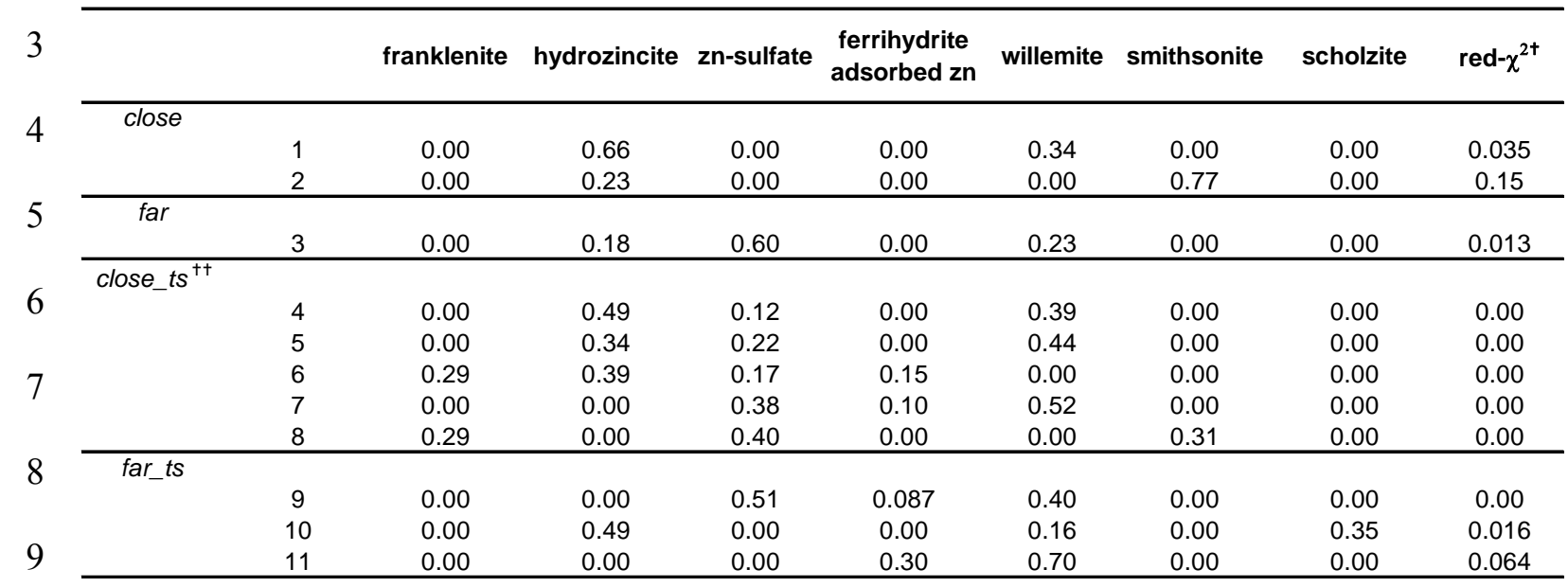

$12+\chi^{2}=\Sigma[(\text { fit }- \text { data }) / \varepsilon]^{2} /\left(\mathrm{N}_{\text {data }}-\mathrm{N}_{\text {components }}\right)$ is the chi-square statistic. Here $\varepsilon$ is the

13 estimated uncertainty in the normalized XANES data (taken as 0.01 for all data). The

14 sum is over $\mathrm{N}_{\text {data }}$ points and $\mathrm{N}_{\text {components }}$ is the number of components in the fit. The

15 total percentage was constrained to be $100 \%$ in all fits. Typical uncertainties in the

16 fractions listed for each standard component are 5\%.

17

$18{ }^{+\dagger}$ ts: thin section

19

20 
1 Table 4: Fractions of $\mathrm{Cu}$ species in selected ' $\mathrm{Cu}$-hotspots' in the area close to the soil

2 micropore in a thin section (ts).

3

4

\begin{tabular}{lcccccc}
\hline & & malachite & nissonite & azurite & calcosiderite & red- $\chi^{2}$ \\
\hline close_ts & & & & & & \\
& 1 & 0.69 & 0.31 & 0.00 & 0.00 & 19.55 \\
& 2 & 0.00 & 0.00 & 0.70 & 0.30 & 121.63 \\
\hline
\end{tabular}

$6+{ }^{+} \chi^{2}=\Sigma[(\text { fit }- \text { data }) / \varepsilon]^{2} /\left(\mathrm{N}_{\text {data }}-\mathrm{N}_{\text {components }}\right)$ is the chi-square statistic. Here $\varepsilon$ is the

7 estimated uncertainty in the normalized XANES data (taken as 0.01 for all data). The

8 sum is over $\mathrm{N}_{\text {data }}$ points and $\mathrm{N}_{\text {components }}$ is the number of components in the fit. The

9 total fractions was constrained to be $100 \%$ in all fits. Typical uncertainties in the

10 fractions listed for each standard component are 5\%.

11

12 


\section{$1 \quad$ Figure 1}

2

Organic matter coating

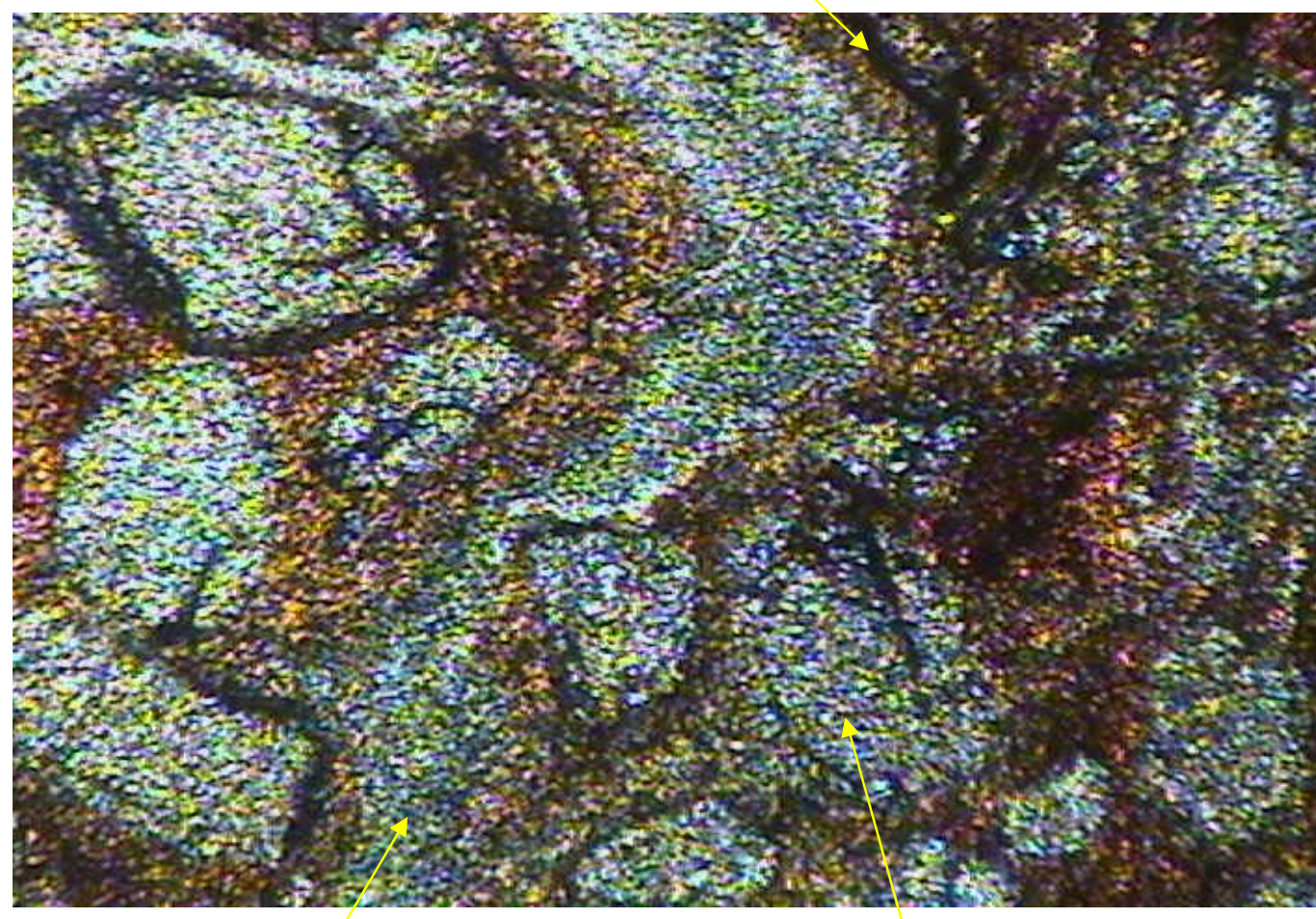

pore

Quartz particle

$1 \mathrm{~mm}$ 


$$
\bar{E}=
$$


Figure 3

Repeat colour scale as for Figure 2

3
4
5

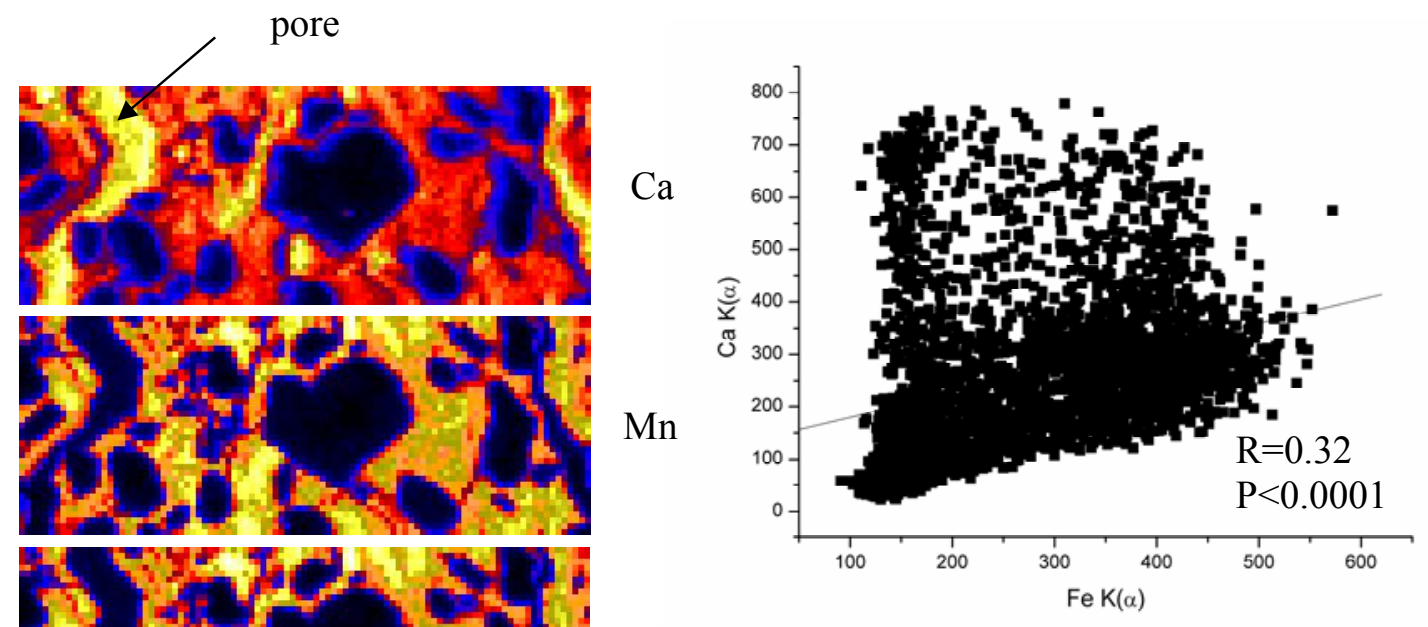

$\mathrm{Fe}$

$\mathrm{Cu}$
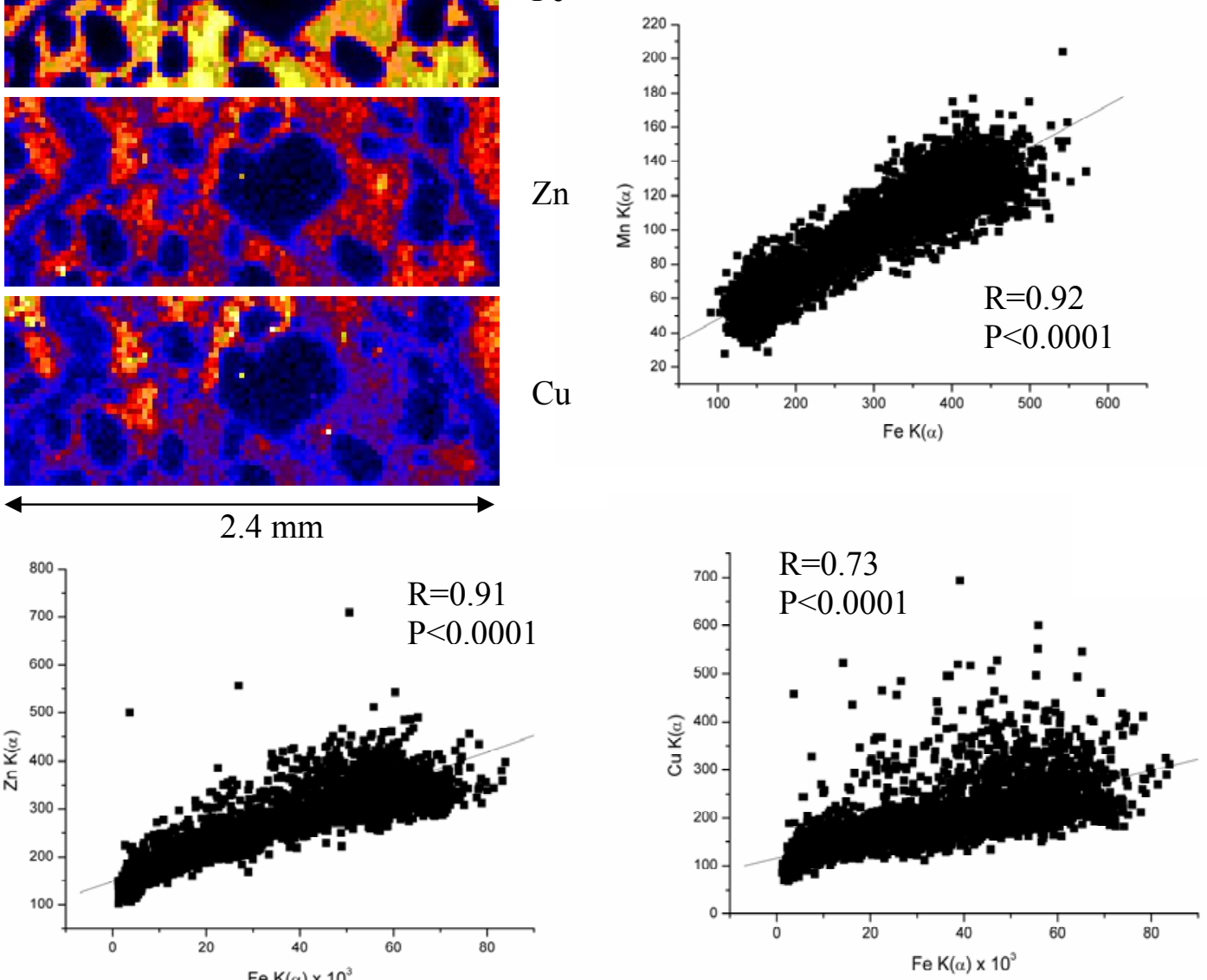


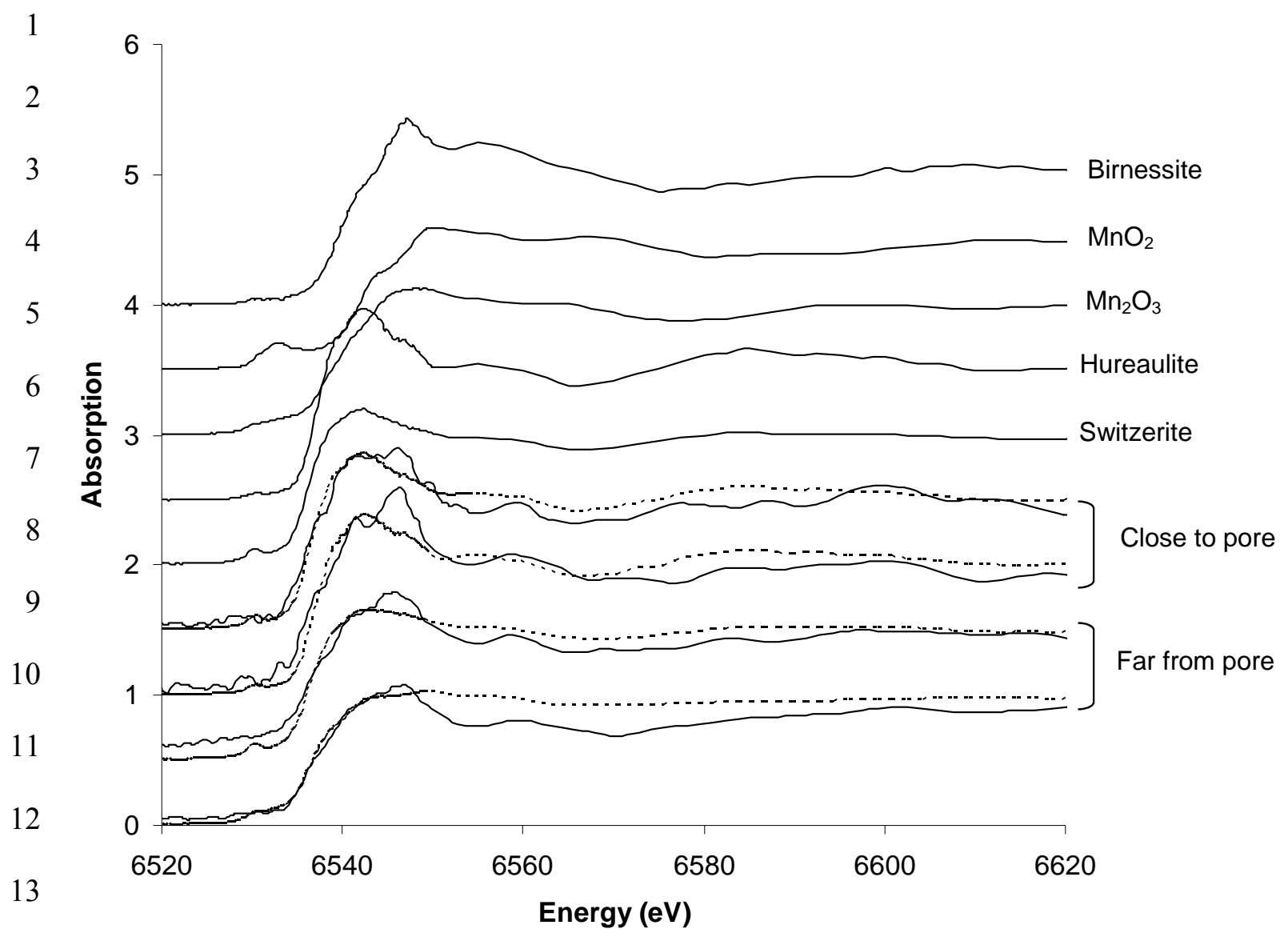

$14 \quad$ spectrum

15 -..- fit

16

17

18

19

20

21

22

23

Figure 4 


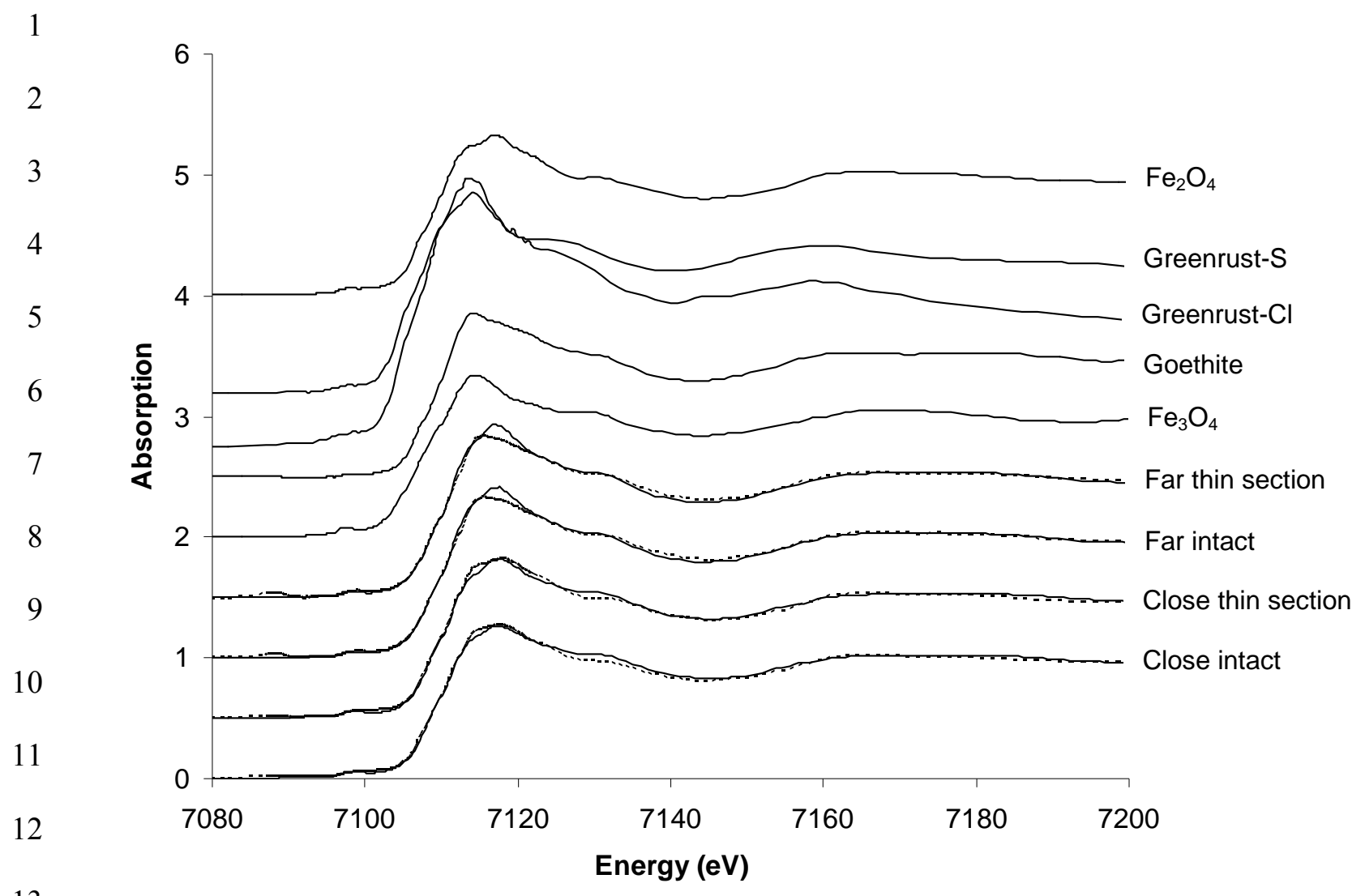

13

14 f fit

15

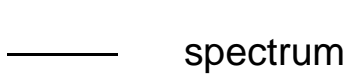

16

17

18

19

20

21

22

Figure 5

23 


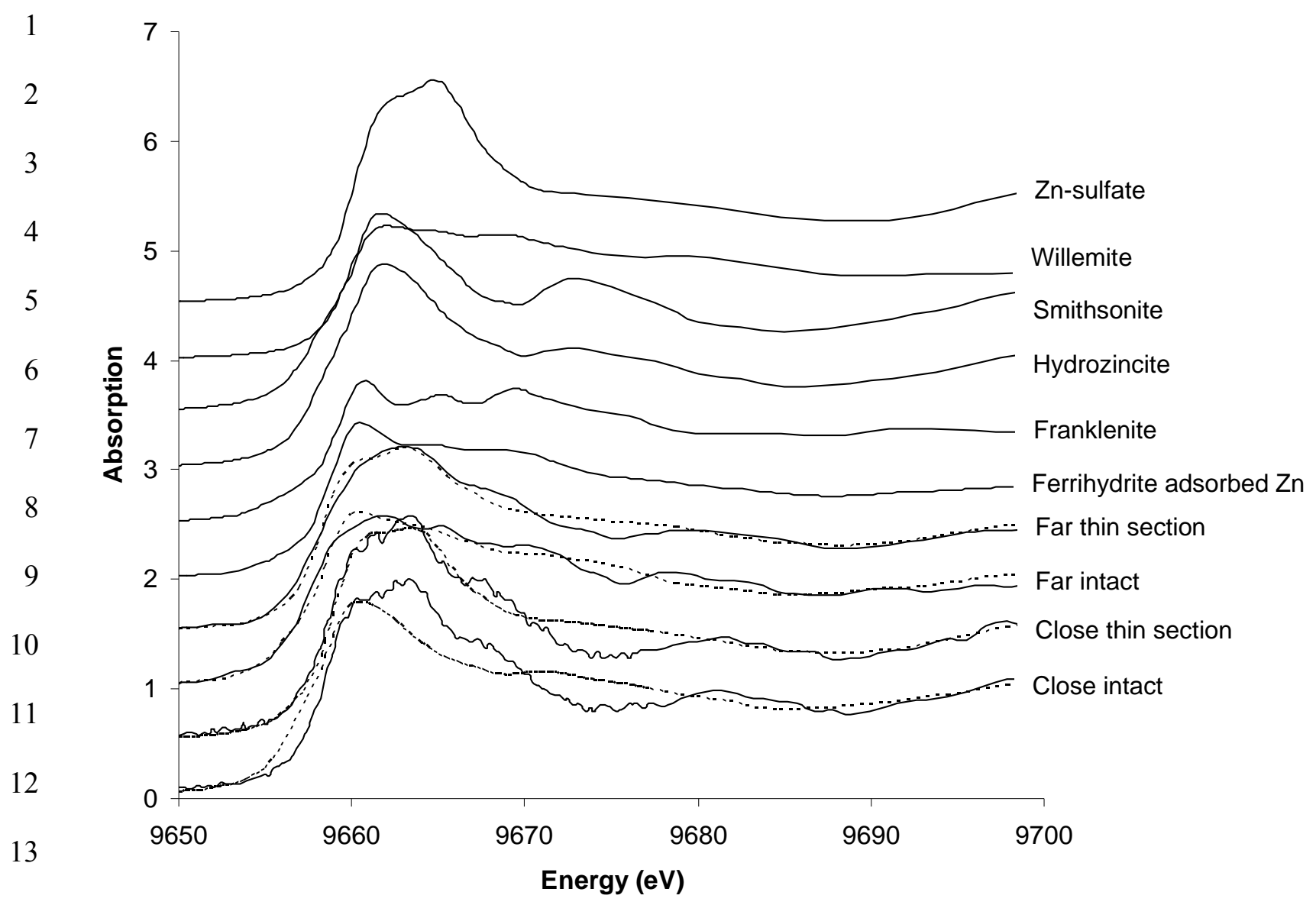

14

15

-.--.- Fit

$16-$ Spectrum

17

18

19

20

21

22

23

24

Figure 6

25 

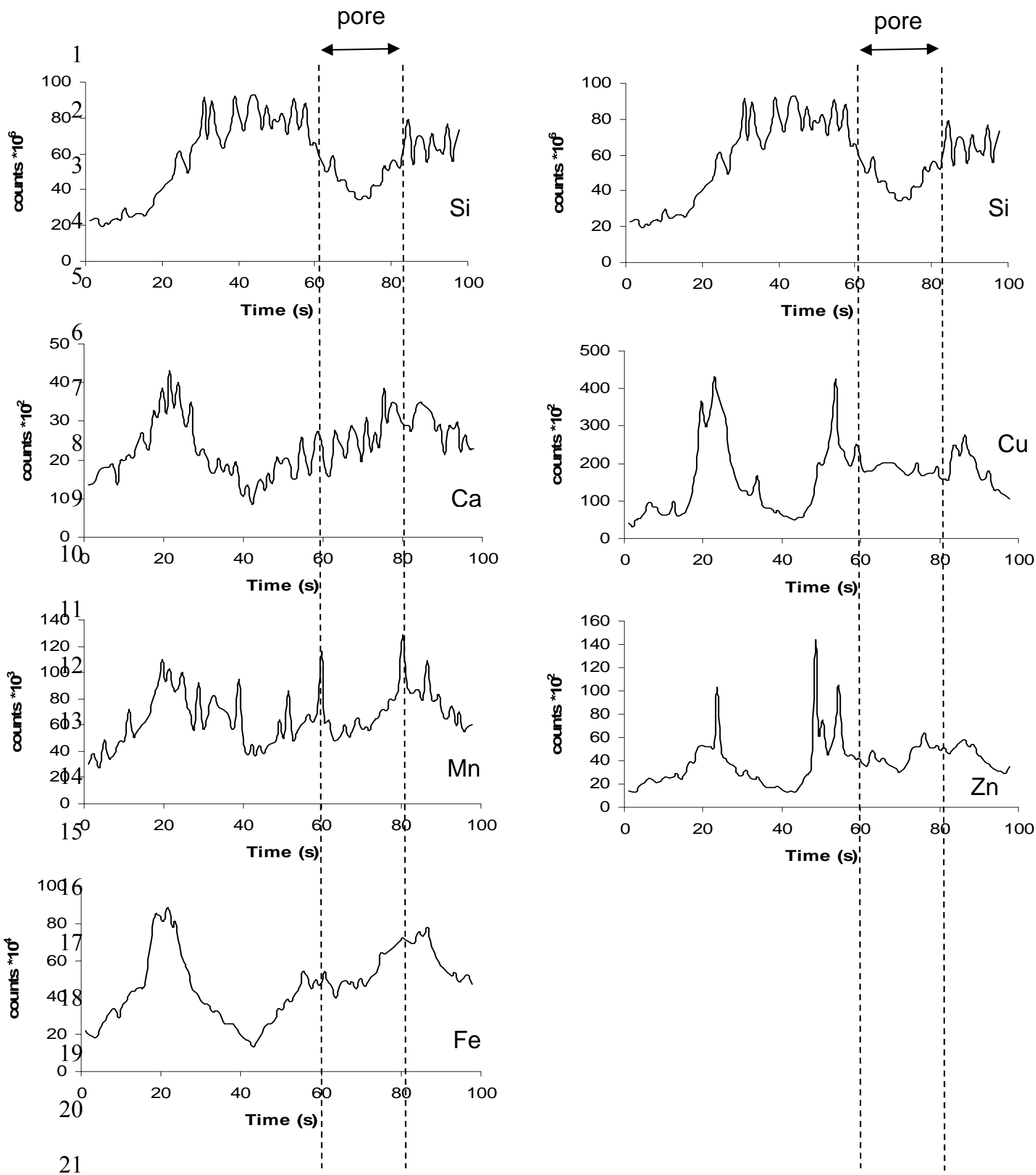

Figure 7 

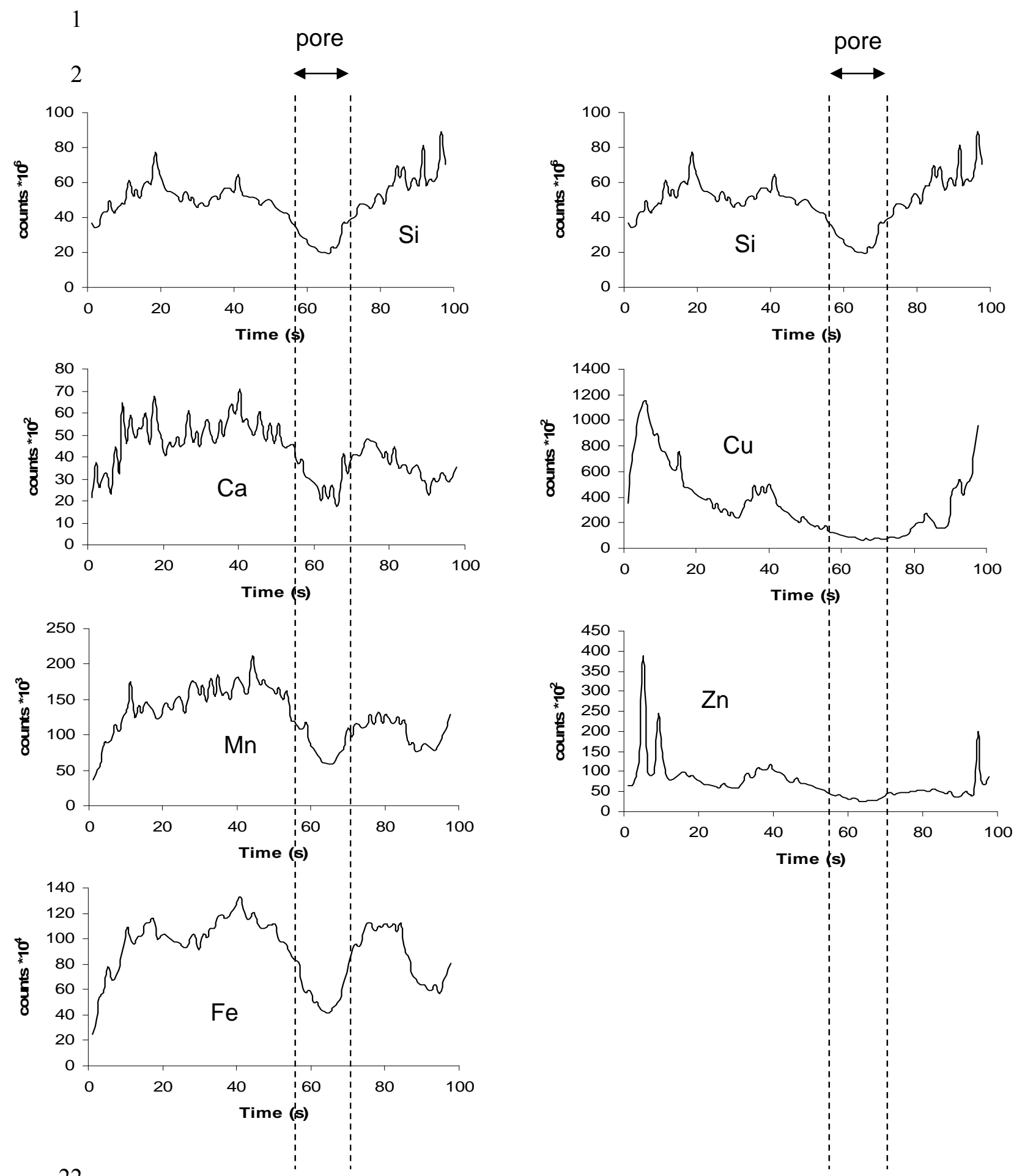